\title{
Fibronectin binding of Lactobacillus species isolated from women with and without bacterial vaginosis
}

\author{
ELISABETH NAGY, G. FRÖMAN* and P.-A. MÅRDH* \\ Department of Clinical Microbiology, Albert Szent-Györgyi Medical University, PO Box 482, \\ H-6701 Szeged, Hungary and "Institute of Clinical Bacteriology, University of Uppsala, Box 552, \\ S-751 22 Uppsala, Sweden
}

\begin{abstract}
Summary. Lactobacilli isolated from the vaginas of healthy women ( 39 strains) and from the vaginal discharge of women with bacterial vaginosis (15 strains) were investigated for their binding to ${ }^{125} \mathrm{I}$-fibronectin. Nine of the 54 strains bound fibronectin at $\mathrm{pH} 7 \cdot 2$. The binding capacity of these nine strains was about the same as that observed with Staphylococcus aureas Cowan 1. The binding was specific; an excess of unlabelled fibronectin or its amino-terminal 29-kDa fragment effectively competed for binding, whereas bovine serum albumin, human IgG and orosomucoid did not. Incubation of lactobacilli with fibronectin for different periods revealed a time-dependent increase in binding. Lowering the $\mathrm{pH}$ to 4.0 increased the binding capacity of all of the lactobacilli tested; binding occurred with strains that had previously failed to bind at $\mathrm{pH} 7 \cdot 2$. The increased binding of lactobacilli to fibronectin at a low $\mathrm{pH}$ may play a role in the maintenance of the ecological balance of the vagina.
\end{abstract}

\section{Introduction}

Bacterial vaginosis is a syndrome characterised by a homogeneous thin discharge with a $\mathrm{pH}$ value $>4.7$, a fishy amine odour and the presence of clue cells. ${ }^{1}$ Besides these clinical signs, a significant decrease of the normal Lactobacillus flora of the vagina can be seen with a simultaneously increased concentration of a mixed anaerobic flora including Mobiluncus spp, together with Gardnerella vaginalis and mycoplasmas. ${ }^{2,3}$ The mechanisms that control the composition of the vaginal microflora under different circumstances are only partly understood. The low $\mathrm{pH}$ of the vaginal fluid in healthy premenopausal women is probably maintained by the lactobacilli, that metabolise the glycogen in the vaginal epithelium through glucose to lactic acid. ${ }^{4}$ The antibiosis between lactobacilli and other bacteria, ${ }^{5}$ due in part to $\mathrm{H}_{2} \mathrm{O}_{2}{ }^{6}$ or bacteriocin ${ }^{7}$ production, and the adherence of the different bacteria to vaginal epithelial cells, ${ }^{8-10}$ are only some factors that may influence the ecological balance of the vagina.

Fibronectin is a high-mol. wt glycoprotein found in soluble form in plasma and in different body fluids such as the vaginal fluid. ${ }^{11,12}$ Insoluble or matrix fibronectin is a web of polymerised fibronectin that coats cell surfaces, basement membranes and mucosal or cutaneous surfaces. ${ }^{13}$ Fibronectin has several adhesive functions and may reasonably be assumed to be a central and indispensable component in a number of

Received 13 May 1991; revised version accepted 2 Sept. 1991. physiologically diverse systems. Fibronectin may play a dual role in host-parasite interactions. ${ }^{14}$ Favourably for the host, fibronectin provides an ideal foundation material to which structural macromolecules or cells such as members of the indigenous flora can adhere. In this way, it may enhance the attachment of symbiotic organisms to mucosal surfaces, thus establishing the protective normal bacterial flora. On the other hand, the binding of pathogenic bacteria to fibronectin can be the first step in the infective process. Fibronectin binding has been proposed as the initial step in infection caused by several pathogens, e.g., Staphylococcus aureus, ${ }^{15} \quad \beta$-haemolytic streptococci, ${ }^{16,17}$ Escherichia coli, ${ }^{18}$ Salmonella enteritidis ${ }^{19}$ and Treponema pallidum. ${ }^{20}$ There are only limited data about the fibronectin binding of the members of the normal mucosal flora.

These considerations prompted us to perform a systematic screening and characterisation of the fibronectin binding of lactobacilli isolated from the vaginas of healthy women and from others suffering from bacterial vaginosis.

\section{Materials and methods}

\section{Bacteria}

Studies were performed on 54 Lactobacillus isolates from the vaginal fluid of healthy women ( 39 strains) and from the vaginal discharge of women with bacterial vaginosis (15 strains). The biochemical 
characterisation of the lactobacilli was with the API 50 $\mathrm{CH}$ kit (bioMerieux). Fibronectin binding was also tested with four additional Lactobacillus reference strains from the culture collection of the University of Göteborg (L. sacidophilus CCUG 5917, L. fermentum CCUG 21453, L. casei CCUG 18011 and L. delbrueckii CCUG 19776) and one L. acidophilus strain isolated from the Lactinette capsule (Biologa AB, Sweden), which is recommended for use in cases of bacterial vaginosis to re-establish the dominance of the lactobacillary flora. $S$. aureus strain Cowan 1 was selected as a positive control strain for fibronectin binding. Before use, the Lactobacillus strains were cultured on Rogosa Agar (Difco) plates at $37^{\circ} \mathrm{C}$ in an anaerobic environment (GasPak system; BBL) for $48 \mathrm{~h}$. Bacteria used to measure the binding of ${ }^{125}$ I-fibronectin were harvested in $5 \mathrm{ml}$ of phosphate-buffered saline (PBS; $\mathrm{pH} 7 \cdot 2$ ), centrifuged at $1500 \mathrm{~g}$ for $10 \mathrm{~min}$ and washed once with the same buffer. The final density of the suspension was adjusted to $10^{10} \mathrm{cfu} / \mathrm{ml}$. This bacterial suspension could be stored at $-20^{\circ} \mathrm{C}$ without changes in the fibronectin binding capacity.

\section{${ }^{125}$ I-fibronectin binding}

Labelled fibronectin was a gift from M. Lindberg (Department of Microbiology, Swedish University of Agricultural Sciences, Uppsala, Sweden). Fibronectin was isolated from bovine plasma and labelled with ${ }^{125} \mathrm{I}$ by the chloramine-T method. ${ }^{21}$ The binding of ${ }^{125} \mathrm{I}$ fibronectin to the bacteria was determined by a modification of the procedure described previously. ${ }^{22}$ Briefly, bacterial suspensions stored at $-20^{\circ} \mathrm{C}$ were diluted 10 -fold in PBS with Tween $800.1 \% \mathrm{v} / \mathrm{v}$. To $2.9 \mathrm{ml}$ of this suspension, ${ }^{125}$ I-fibronectin $2 \times 10^{4} \mathrm{cpm}$ in $0.1 \mathrm{ml}$ (specific activity $8.2 \mu \mathrm{Ci} / \mu \mathrm{g}$ ) was added. Tubes containing reaction mixtures were incubated with rotation for $2 \mathrm{~h}$ at room temperature. The samples were then centrifuged at $1500 \mathrm{~g}$ for $20 \mathrm{~min}$. The supernates were aspirated and the radioactivity associated with the pellet was measured in a $\gamma$-counter (LKB Wallac Clinigamma 127, Turku, Finland). The analyses were always made in duplicate. The binding of fibronectin was expressed as a percentage of the total activity after subtraction of the background values. The fibronectin binding of lactobacilli at different $\mathrm{pH}$ values was tested in the same way. Citratephosphate buffer of $\mathrm{pH} 7 \cdot 0,6.0,5.0$ and 4.0 was used, or phosphate buffer of $\mathrm{pH} 8.0$ supplemented with Tween $800.1 \% \mathrm{v} / \mathrm{v}$. Control tubes containing buffer at different $\mathrm{pH}$ values were also used without bacteria and with the same amount of ${ }^{125}$ I-fibronectin.

\section{Inhibition of ${ }^{125}$ I-fibronectin binding}

Unlabelled fibronectin isolated from bovine plasma (Extraco, Sweden), the 29-kDa amino-terminal fragment of human fibronectin, isolated as described by Fröman et al.,18 immunoglobulin G (IgG) (KabiVitrum, Sweden), orosomucoid (Waddie,
Edinburgh) and bovine serum albumin (Sigma), each dissolved in $0.2 \mathrm{M}$ phosphate buffer $(\mathrm{pH} \mathrm{7.2)}$, were used to study the inhibition of ${ }^{125}$ I-fibronectin binding. Competitive inhibition assays were performed in the same way as the binding assays except that $10 \mu \mathrm{g}$ or $100 \mu \mathrm{g}$ of unlabelled fibronectin, its $29-\mathrm{kDa}$ fragment or one of the other proteins was added to the test-tubes before the addition of ${ }^{125}$ I-fibronectin. The extent of inhibition was expressed as a percentage of the total binding of ${ }^{125} \mathrm{I}$-fibronectin to the bacteria without other proteins.

\section{Ultrasound treatment of lactobacilli}

Diluted suspensions (10-fold in PBS + Tween 80 $0.1 \%$ or citrate-phosphate buffer, $\mathrm{pH} 4 \cdot 0,+$ Tween 80 $0 \cdot 1 \%$ ) of $L$. jensenii strain 34 and $L$. acidophilus strain 71 were treated with ultrasound (Bransonic, Model B-2200, Dantury, CT, USA) for $1,3,5$ or $10 \mathrm{~min}$ before the addition of ${ }^{125}$ I-fibronectin. After incubation for $2 \mathrm{~h}$, the binding of fibronectin was determined as already described; $100 \mu \mathrm{l}$ of the supernate of the ultrasound-treated $(10 \mathrm{~min})$ undiluted cell suspensions was used to inhibit the binding of ${ }^{125} \mathrm{I}$ fibronectin.

\section{Results}

Of 54 isolates of lactobacilli tested in the ${ }^{125} \mathrm{I}$ fibronectin binding assay at $\mathrm{pH} 7 \cdot 2$, nine strains, all from healthy women, bound fibronectin, whereas 45 strains (30 from healthy women and 15 from patients with bacterial vaginosis) did not. When the fibronectin binding values were compared with that of $S$. aureus Cowan 1, which was taken as $100 \%$, the nine positive Lactobacillus strains could be ranged in three categories-high, medium and low binders (fig. 1). All four Lactobacillus strains from the type culture collection of the University of Göteborg and the $L$. acidophilus isolate from the Lactinett capsule did not bind fibronectin at $\mathrm{pH} 7 \cdot 2$.

Specificity of ${ }^{125}$ I-fibronectin binding was tested by competitive inhibition experiments with a representative strain from each of the three categories. The ${ }^{125} \mathrm{I}-$ fibronectin binding was almost completely inhibited in all three strains by $100 \mu \mathrm{g}$ of unlabelled fibronectin (table I). The 29-kDa fragment of fibronectin inhibited the binding of ${ }^{125}$ I-fibronectin to almost the same degree as intact fibronectin, which strongly indicates that the lactobacilli interact with the amino-terminal domain of the fibronectin molecule. No marked inhibition of fibronectin binding was observed with human IgG, orosomucoid or bovine serum albumin.

The fibronectin binding of the nine Lactobacillus strains with different binding capacities and that of 15 Lactobacillus strains which proved to be non-binders at $\mathrm{pH} 7.2$ was determined at different $\mathrm{pH}$ values. A marked increase in the binding capacity was observed in all groups of lactobacilli tested which paralleled the 


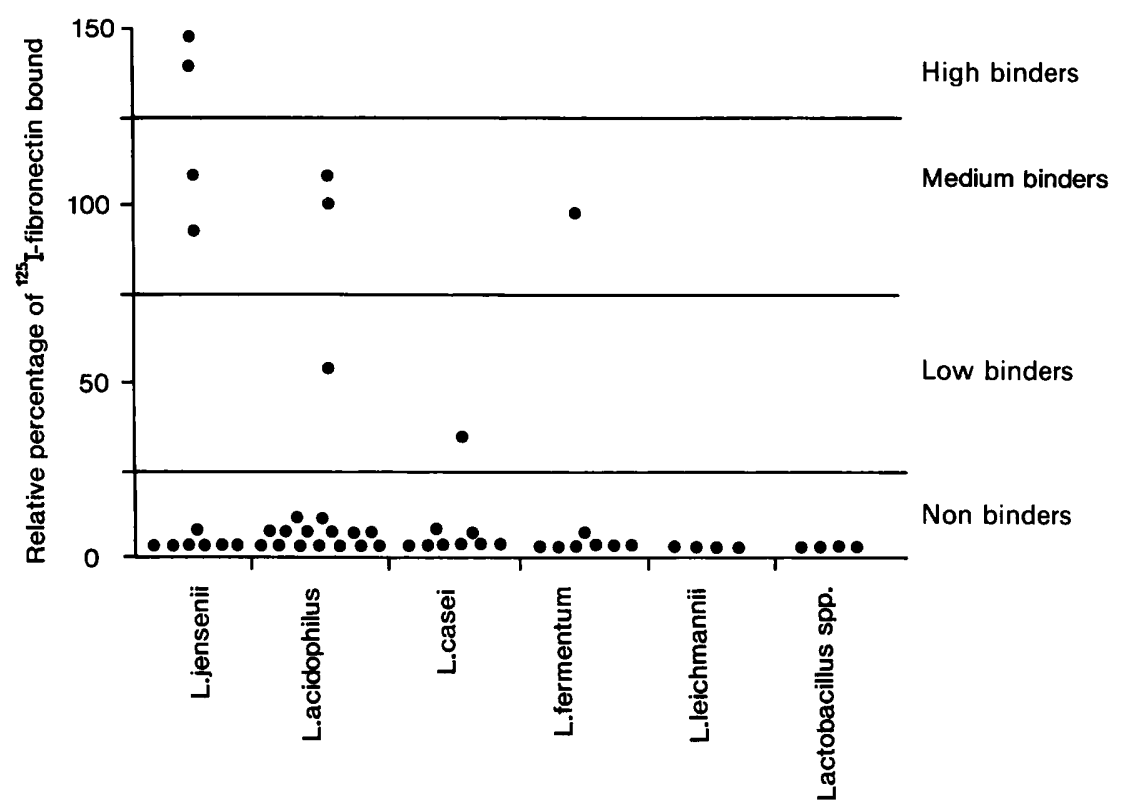

Fig. 1. Relative ${ }^{125} \mathrm{I}$-fibronectin binding of 54 clinical isolates of lactobacilli at $\mathrm{pH} 7 \cdot 2$; binding by $S$. aureus strain Cowan 1 was taken as $100 \%$.

Table I. Specificity of ${ }^{125}$ I-fibronectin binding by $L$. jensenii (high), L. acidophilus (medium) and L. caseii (low) at $\mathrm{pH} \mathrm{7.2}$

\begin{tabular}{|c|c|c|c|c|c|c|}
\hline \multirow{2}{*}{$\begin{array}{l}\text { Species } \\
\text { and } \\
\text { strain } \\
\text { no. }\end{array}$} & \multirow{2}{*}{$\begin{array}{l}\text { Amount } \\
\text { of } \\
\text { protein } \\
\text { added } \\
(\mu \mathrm{g})\end{array}$} & \multicolumn{5}{|c|}{$\begin{array}{l}\text { Percentage of }{ }^{125} \text { I-fibronectin bound by } \\
\text { bacteria in the presence of }\end{array}$} \\
\hline & & $\begin{array}{l}\text { bovine } \\
\text { fibronectin }\end{array}$ & $\begin{array}{l}\text { 29-kDa } \\
\text { fragment }\end{array}$ & $\underset{\text { IgG }}{\text { human }}$ & $\begin{array}{l}\text { oroso- } \\
\text { mucoid }\end{array}$ & $\begin{array}{l}\text { bovine } \\
\text { albumin }\end{array}$ \\
\hline $\begin{array}{l}\text { L. jensenii } \\
\text { strain } 34\end{array}$ & $\begin{array}{r}10 \\
100\end{array}$ & $\begin{array}{l}17 \\
10\end{array}$ & $\begin{array}{l}24 \\
20\end{array}$ & $\begin{array}{l}90 \\
78\end{array}$ & $\begin{array}{l}89 \\
86\end{array}$ & $\begin{array}{l}84 \\
78\end{array}$ \\
\hline $\begin{array}{l}\text { L. acidophilus } \\
\text { strain } 71\end{array}$ & $\begin{array}{r}10 \\
100\end{array}$ & $\begin{array}{r}13 \\
6\end{array}$ & $\begin{array}{l}20 \\
18\end{array}$ & $\begin{array}{l}93 \\
90\end{array}$ & $\begin{array}{l}94 \\
85\end{array}$ & $\begin{array}{l}100 \\
100\end{array}$ \\
\hline $\begin{array}{l}\text { L. caseii } \\
\text { strain } 33\end{array}$ & $\begin{array}{r}10 \\
100\end{array}$ & $\begin{array}{r}10 \\
8\end{array}$ & $\begin{array}{l}13 \\
10\end{array}$ & $\begin{array}{r}100 \\
94\end{array}$ & $\begin{array}{l}92 \\
86\end{array}$ & $\begin{array}{l}99 \\
96\end{array}$ \\
\hline
\end{tabular}

* Percentage of total binding by the bacteria incubated without the unlabelled protein.

decrease in $\mathrm{pH}$. At $\mathrm{pH} 7 \cdot 0$, the four categories of strains could easily be differentiated, i.e., high, medium and low binders and non-binders. However, at $\mathrm{pH} 4 \cdot 0$ all strains displayed a markedly higher binding of ${ }^{125} \mathrm{I}$ fibronectin, with no differences between the members of the originally established categories. Even Lactobacillus strains which proved to be non-binders at pH 7.0 ( $<1 \%$ of total radioactivity added) exhibited a much higher ${ }^{125}$ I-fibronectin binding than that of the reference strain $S$. aureus Cowan 1 at $\mathrm{pH} 7.0$. With increase of the $\mathrm{pH}$ to 8.0 , the binding capacity of the lactobacilli was less than that observed at $\mathrm{pH} 7.0$ in every group (table II). We also tested the influence of the $\mathrm{pH}$ value on the binding capacity of $S$. aureus Cowan 1. An increase in its ${ }^{125}$ I-fibronectin binding was likewise observed in parallel with the decrease of the $\mathrm{pH}$ (from $6.5 \%$ of total radioactivity at $\mathrm{pH} 7.2$ to $16 \%$ at $\mathrm{pH} 4 \cdot 0$ ).

Inhibition experiments with unlabelled fibronectin and its $29-\mathrm{kDa}$ fragment were done to confirm the specificity of the binding of labelled fibronectin at $\mathrm{pH}$ 4.0. A representative strain from each of the four categories already described was used (table III). For all four strains, inhibition of ${ }^{125}$ I-fibronectin binding was observed in the presence of $100 \mu \mathrm{g}$ of unlabelled fibronectin but this proved to be less than that measured at $\mathrm{pH} 7 \cdot 2$. The $29-\mathrm{kDa}$ fragment of fibronectin displayed a slightly greater inhibition. However, human IgG, orosomucoid and bovine serum albumin did not inhibit the binding of the labelled fibronectin at pH 4.0.

The kinetics of ${ }^{125}$ I-fibronectin binding at different $\mathrm{pH}$ values was investigated with $L$. jensenii strain 14 , a high-binding strain. The binding was found to be timedependent, with a maximum after incubation for $2 \mathrm{~h}$ at $\mathrm{pH} 7.0$ (fig. 2). At $\mathrm{pH} 4 \cdot 0$, the binding of fibronectin to $L$. jensenii strain 14 was very rapid and the percentage of protein bound after incubation for $15 \mathrm{~min}$ did not change appreciably during further incubation.

Cells of $L$. jensenii strain 34 and L. acidophilus strain 71 were treated by ultrasound for different periods. Ultrasound treatment for $10 \mathrm{~min}$ before adding the ${ }^{125}$ I-labelled fibronectin to the reaction mixture completely abolished the binding of fibronectin at $\mathrm{pH} 7 \cdot 2$, 
Table II. Effect of $\mathrm{pH}$ on ${ }^{125}$ I-fibronectin binding of lactobacilli

\begin{tabular}{|c|c|c|c|c|c|c|}
\hline \multirow{2}{*}{$\begin{array}{l}\text { Species } \\
\text { and } \\
\text { strain } \\
\text { no. }\end{array}$} & \multirow{2}{*}{$\begin{array}{c}\text { Capacity } \\
\text { of } \\
\text { binding } \\
\text { at } \mathrm{pH} 7 \cdot 0\end{array}$} & \multicolumn{5}{|c|}{$\begin{array}{c}\text { Percentage of }{ }^{125} \mathrm{I} \text {-fibronectin } \\
\text { binding at } \mathrm{pH}^{*}\end{array}$} \\
\hline & & $8 \cdot 0$ & $7 \cdot 0$ & 6.0 & $5 \cdot 0$ & $4 \cdot 0$ \\
\hline $\begin{array}{l}\text { L. jensenii } \\
\text { strain } 34\end{array}$ & high & 5 & 11 & 16 & 20 & 32 \\
\hline $\begin{array}{l}\text { L. acidophilus } \\
\text { strain } 71\end{array}$ & medium & 3 & 5 & 11 & 14 & 28 \\
\hline $\begin{array}{l}\text { L. caseii } \\
\text { strain } 33\end{array}$ & low & $<1$ & 2 & 5 & 10 & 29 \\
\hline $\begin{array}{l}\text { L. fermentum } \\
\text { strain } 56\end{array}$ & "non" & $<1$ & $<1$ & 4 & 18 & 34 \\
\hline
\end{tabular}

* Binding of ${ }^{125} \mathrm{I}$-fibronectin expressed as a percentage of the total activity after subtracting the background values.

Table III. Specificity of ${ }^{125}$ I-fibronectin-binding of different strains of lactobacilli at $\mathrm{pH} 4 \cdot 0$

\begin{tabular}{|c|c|c|c|c|c|c|}
\hline \multirow{2}{*}{$\begin{array}{c}\text { Species } \\
\text { and } \\
\text { strain } \\
\text { no. }\end{array}$} & \multirow{2}{*}{$\begin{array}{l}\text { Amount } \\
\text { of } \\
\text { protein } \\
\text { added } \\
(\mu \mathrm{g})\end{array}$} & \multicolumn{5}{|c|}{$\begin{array}{l}\text { Percentage of }{ }^{125} \text { I-fibronectin bound by } \\
\text { bacteria in the presence of* }\end{array}$} \\
\hline & & $\begin{array}{l}\text { bovine } \\
\text { fibronectin }\end{array}$ & $\begin{array}{l}29-\mathrm{kDa} \\
\text { fragment }\end{array}$ & $\begin{array}{l}\text { human } \\
\text { IgG }\end{array}$ & $\begin{array}{l}\text { oroso- } \\
\text { mucoid }\end{array}$ & $\begin{array}{l}\text { bovine } \\
\text { albumin }\end{array}$ \\
\hline $\begin{array}{l}\text { L. jensenii } \\
\text { strain } 34\end{array}$ & $\begin{array}{r}10 \\
100\end{array}$ & $\begin{array}{l}71 \\
60\end{array}$ & $\begin{array}{l}62 \\
55\end{array}$ & $\begin{array}{l}92 \\
83\end{array}$ & $\begin{array}{l}90 \\
85\end{array}$ & $\begin{array}{l}94 \\
82\end{array}$ \\
\hline $\begin{array}{l}\text { L. acidophilus } \\
\text { strain } 71\end{array}$ & $\begin{array}{r}10 \\
100\end{array}$ & $\begin{array}{l}78 \\
61\end{array}$ & $\begin{array}{l}54 \\
53\end{array}$ & $\begin{array}{r}100 \\
95\end{array}$ & $\begin{array}{l}95 \\
92\end{array}$ & $\begin{array}{l}99 \\
98\end{array}$ \\
\hline $\begin{array}{l}\text { L. caseii } \\
\text { strain } 33\end{array}$ & $\begin{array}{r}10 \\
100\end{array}$ & $\begin{array}{l}72 \\
58\end{array}$ & $\begin{array}{l}58 \\
53\end{array}$ & $\begin{array}{r}100 \\
91\end{array}$ & $\begin{array}{l}92 \\
87\end{array}$ & $\begin{array}{l}98 \\
90\end{array}$ \\
\hline $\begin{array}{l}\text { L. fermentum } \\
\text { strain } 56\end{array}$ & $\begin{array}{r}10 \\
100\end{array}$ & $\begin{array}{l}75 \\
55\end{array}$ & $\begin{array}{l}60 \\
57\end{array}$ & $\begin{array}{r}100 \\
92\end{array}$ & $\begin{array}{l}90 \\
82\end{array}$ & $\begin{array}{l}97 \\
92\end{array}$ \\
\hline
\end{tabular}

* Percentage of total binding by the bacteria incubated without the unlabelled protein.

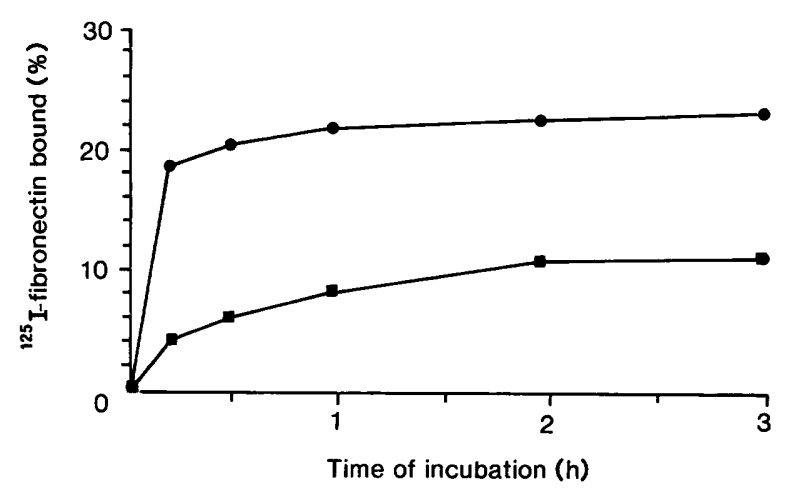

Fig. 2. Time curve of ${ }^{125} \mathrm{I}$-fibronectin binding by $L$. jensenii strain 14 at $\mathrm{pH} 7.2$ ) and $\mathrm{pH} 4.0$

whereas $<5$ min treatment did not influence binding. The binding of fibronectin by untreated cells was not inhibited by adding $100 \mu \mathrm{l}$ of the supernate of the ultrasound-treated undiluted cells to the reaction mixture.

\section{Discussion}

Lactobacilli compose the predominant vaginal flora of premenopausal women without apparent genital infections. ${ }^{2}$ It has been postulated that lactobacilli are responsible for the low vaginal $\mathrm{pH}(3 \cdot 3-4 \cdot 5)$, by production of lactic acid from glycogen. ${ }^{4}$ Such a low $\mathrm{pH}$ value would be expected to inhibit the growth of non-acidophilic organisms, e.g., mixed anaerobic flora seen in bacterial vaginosis or other aerobic pathogens, while stimulating the growth of acidophilic organisms such as lactobacilli.

The adherence of lactobacilli to washed vaginal epithelial cells in vitro has been studied by several authors. ${ }^{8-10}$ Pathogens such as group B streptococci, Neisseria gonorrhoeae and G. vaginalis were reported by Mårdh and Weström ${ }^{8}$ to adhere better than lactobacilli. On the other hand, Sobel et al. ${ }^{9}$ reported that lactobacilli and some vaginal pathogens adhered equally. Wood et al. ${ }^{10}$ investigated the adherence of lactobacilli isolated from healthy women and could not detect any differences in their adherence to washed vaginal epithelial cells in vitro at $\mathrm{pH} \mathrm{4.8,6.0} \mathrm{and} \mathrm{7.2.}$

Fibronectin is a large glycoprotein of $c .440 \mathrm{kDa}$; it is widely distributed in different body fluids and can be secreted on to and coat mucosal surfaces. ${ }^{11,13,14}$ Antonas et al. ${ }^{23}$ reported fibronectin levels as high as $90-140 \mu \mathrm{g} / \mathrm{ml}$ in the vaginal fluid during menses, whereas the levels were low $(3-5 \mu \mathrm{g} / \mathrm{ml})$ at the end of the menstrual cycle. Cohen et al. ${ }^{7}$ measured the fibronectin content of the vaginal fluid of patients with 
acute gonococcal cervicitis and that of non-infected control women. The concentrations of fibronectin were $0 \cdot 2-30 \mu \mathrm{g} / \mathrm{ml}$, without significant differences between the patients and healthy women.

In the present study, marked differences were observed in the capacities of Lactobacillus isolates to bind ${ }^{125}$ I-labelled fibronectin when this was tested at different $\mathrm{pH}$ values. Only nine of 54 vaginal isolates (all from the vaginal fluid of healthy women) bound ${ }^{125}$ I-fibronectin at $\mathrm{pH} 7 \cdot 2$. This binding should be considered to be specific, because it was inhibited by unlabelled fibronectin or its $29-\mathrm{kDa}$ amino-terminal fragment. The inhibition of binding of ${ }^{125}$ I-fibronectin by the $29-\mathrm{kDa}$ fragment indicates that the lactobacilli bind to the amino-terminal domain of the fibronectin molecule, as do $S$. aureus strains ${ }^{15,16,22}$ or streptococci. ${ }^{16,17}$ On lowering the $\mathrm{pH}$ from 8.0 to 4.0 , increased binding of fibronectin was observed with all of these nine Lactobacillus isolates. Fifteen further isolates, that were originally found to be non-binders, isolated from healthy women (10 strains) and from women with bacterial vaginosis (five strains), also showed increased binding of ${ }^{125}$ I-fibronectin at lower $\mathrm{pH}$ values. The binding of fibronectin at these low $\mathrm{pH}$ values proved to be only partially specific, because only $40-45 \%$ of the radiolabelled fibronectin binding could be inhibited by $100 \mu \mathrm{g}$ of unlabelled fibronectin or by its $29-\mathrm{kDa}$ fragment. The increased non-specific ${ }^{125}$ I-fibronectin binding at $\mathrm{pH} 4.0$ could be due to nonspecific charge interactions taking place at a $\mathrm{pH}$ value below the iso-electric point of fibronectin. However, a substantial part of the binding is still specific.

\section{References}

1. Eschenbach DA, Bekassy S, Blackwell A, Ekgren J, Hallén A, Wathne B. The diagnosis of bacterial vaginosis. Scand $J$ Urol Nephrol 1985; Suppl 86: 260-261.

2. Hill GB, Eschenbach DA, Holmes KK. Bacteriology of vagina. Scand J Urol Nephrol 1985; Suppl 86: 23-39.

3. Skarin, A. Mårdh P-A. Comma-shaped bacteria associated with vaginitis. Lancet $1982 ; 1,342$.

4. Wylie JG, Henderson A. Identity of glycogen-fermenting ability of lactobacilli isolated from the vagina of pregnant women. J Med Microbiol 1969; 2: 363-366.

5. Mårdh P-A, Soltész LV. In vitro interactions between lactobacilli and other microorganisms occurring in the vaginal flora. Scand J Infect Dis 1983; Suppl 40: 47-51.

6. Eschenbach DA, Davick PR, Williams BL et al. Prevalence of hydrogen peroxide-producing Lactobacillus species in normal women and women with bacterial vaginosis. $J$ Clin Microbiol 1989; 27: 251-256.

7. Cohen MS, Black JR, Proctor RA, Sparling PF. Host defences and the vaginal mucosa: reevaluation. Scand J Urol Nephrol 1985; Suppl 86: 13-22.

8. Mårdh P-A, Weström L. Adherence of bacteria to vaginal epithelial cells. Infect Immun 1976; 13: 661-666.

9. Sobel JD, Schneider J, Kay D, Levison ME. Adherence of bacteria to vaginal epithelial cells at various times in the menstrual cycle. Infect Immun 1981; 32: 194-197.

10. Wood JR, Sweet RL, Catena A, Hadley WK, Robbie M. In vitro adherence of Lactobacillus species to vaginal epithelial cells. Am J Obstet Gynecol 1985; 153: 740-743.

11. Mosher DF. Physiology of fibronectin. Annu Rev Med 1984; 35 : 561-575.

12. Proctor R. Fibronectin: a brief overview of its structure, function and physiology. Rev Infect Dis 1987; 9 Suppl 4: S317-S321.
Ultrasound treatment abolished binding to fibronectin, presumably by removing surface structures involved in adherence. After ultrasound treatment the supernate did not itself inhibit binding, which suggests removal was associated with configurational changes.

A great number of pathogenic bacteria belonging to different species have recently been studied in respect of their ability to bind to fibronectin. ${ }^{15,16,18-20}$ Their different binding capacities were considered to be an important additional pathogenicity factor for all species studied. However, little is known about the fibronectin binding capacities of the members of the normal bacterial flora and about the possible role of these interactions in the stability of the normal flora on the mucosal surfaces.

Despite the extensive research of the last decades, the vaginal ecosystem is still poorly understood. Different studies show great qualitative and quantitative variations of the occurrence of bacterial species in the vaginal fluid of healthy women. The factors regulating vaginal $\mathrm{pH}$ and the role of $\mathrm{pH}$ in regulating the vaginal flora are not well defined. We observed markedly increased fibronectin binding with all lactobacilli tested at low $\mathrm{pH}$ values. It appears probable that the increased binding of fibronectin by vaginal lactobacilli at these low $\mathrm{pH}$ values, which are normal for the vaginal fluid of healthy women in the fertile period of life, plays an additional role in the maintenance of the ecological balance of the vagina.

This study was supported by a grant from Ekhagastiftelsen, Sweden.

13. Hynes R. Molecular biology of fibronectin. Annu Rev Cell Biol $1985 ; 1: 67-90$.

14. Dunne WM. Fibronectin : the biological Velcro. Clin Microbiol Newslett $1989 ; 11$ : 57-59.

15. Espersen $\mathrm{F}$, Clemmensen I. Isolation of fibronectin-binding protein from Staphylococcus aureus. Infect Immun 1982; 37: $526-531$.

16. Kuusela P, Vartio T, Vuento M, Myhre EB. Attachment of staphylococci and streptococci on fibronectin, fibronectin fragments, and fibrinogen bound to solid phase. Infect Immun 1985; 50: 77-81

17. Switalski LM, Ljungh Á, Rydén C, Rubin $K$, Höök $M$, Wadström $T$. Binding of fibronectin to the surface of group $\mathrm{A}$, group $\mathrm{C}$, and group $\mathrm{G}$ streptococci isolated from human infections. Eur J Clin Microbiol Infect Dis 1982; 1: 381-387.

18. Fröman G, Świtalski LM, Faris A, Wadström T, Höök M Binding of Escherichia coli to fibronectin. $J$ Biol Chem 1984; 259: 14899-14905.

19. Baloda SB, Faris A, Fröman G, Wadström T. Fibronectin binding to Salmonella strains. FEMS Microbiol Lett 1985 28: $1-5$.

20. Thomas DD, Baseman JB, Alderete JF. Enhanced levels of attachment of fibronectin-primed Treponema pallidum to extracellular matrix. Infect Immun 1986; 52: 736-741.

21. Hunter WM. Radioimmunoassay. In: Weir DM (ed) Handbook of experimental immunology. Oxford, Blackwell Scientific. 1978: 14: 1-40.

22. Fröman G, Switalski LM, Speziale $P$, Höök $M$. Isolation and characterization of a fibronectin receptor from Staphylococcus aureus. J Biol Chem 1987; 262: 6564-6571.

23. Antonas KN, Yajko DM, Hardley WK. Assay of fibronectin in vaginal fluid and the role of fibronectin in bacterial colonization. Annual Meeting of the American Society of Microbiology, New Orleans, 1983. Abstract no. 1310. 